\title{
PERTUMBUHAN POPULASI CACING RENIK (Panagrellus redivivus) PADA MEDIA YANG BERBEDA
}

\section{GROWTH OF Panagrellus redivivus POPULATION ON DIFFERENT MEDIA}

\author{
L Arwanto 1a, Mulyana 1, F S Mumpuni ${ }^{1}$ \\ 1Jurusan Perikanan, Fakultas Ilmu dan Bisnis Pertanian, Universitas Djuanda Bogor, Jl. Tol Ciawi No. 1, \\ Kotak Pos 35 Ciawi, Bogor 16720.
}

\begin{abstract}
ABSTRAK
Penelitian ini bertujuan untuk mengetahui pengaruh jenis media terhadap pertumbuhan populasi cacing renik.Rancangan percobaan yang digunakan pada penelitian ini adalah Rancangan Acak Lengkap (RAL) dengan 3 perlakuan dan 3 ulangan.Inokulan yang digunakan adalah cacing renik yang telah dikultur selama 7 minggu.Perlakuan yang diberikan adalah jenis media yang berbeda yaitu bubur gandum (oatmeal), dedak padi, dan tepung tapioka.Parameter yang diamati selama penelitian adalah dinamika populasi, laju pertumbuhan, jumlah individu saat puncak populasi, lama waktu mencapai puncak populasi, dan pH media.Hasil penelitian memperlihatkan bahwa perlakuan jenis media yang berbeda memberikan pengaruh yang berbeda sangat nyata terhadap laju pertumbuhan dan jumlah individu saat puncak populasi $(\mathrm{P}<0,01)$. Perlakuan media bubur gandum menghasilkan laju pertumbuhan terbaik yaitu $45,0 \%$ serta mengalami puncak populasi tercepat selama 2 minggu. Pada media dedak menghasilkan jumlah individu paling sedikit sebanyak 162.563 ekor.

Kata Kunci : Pertumbuhan, populasi, cacing renik.
\end{abstract}

\begin{abstract}
This study aimed to determine media effect on the growth of microscopic worm population. The experimental design in this studyis completely randomized design (CRD) with 3 treatments and 3 replications. Inoculants used are microscopic worms that had been cultured for 7 weeks. Treatments are different types of media, namely porridge oats (oatmeal), rice bran, and tapioca flour. The parameters observed during the study was population dynamics, growth rate, the number of individuals during the peak population, long time reached a peak population, and $\mathrm{pH}$ ofmedia. The results showed that the treatment of different types of media provide highly significant effect on the rate of growth and the number of individuals during the peak of population $(\mathrm{P}<0.01)$. Media treatment oatmeal produce the best growth rate is $45.0 \%$ and experiencing the fastest population peak for 2 weeks. In the media bran produce the number of individuals at least as much as 162563 head.

Keywords: Growth, population, microscopic worms.
\end{abstract}




\section{PENDAHULUAN}

Dalam dunia budidaya ikan yang intensif, terutama di bidang pembenihan ikan hias, masalah pakan memegang peranan yang sangat penting.Secara kualitatif pakan alami tidak dapat digantikan dengan pakan ikan buatan.Selama ini, sebagian besar pakan alami adalah plankton, baik fitoplankton maupun zooplankton.Pakan ini hidup bebas di berbagai perairan, baik perairan tawar, payau, atau laut dan mampu berkembang biak secara cepat.Beberapa contoh di antaranya adalah Rotifera (Branchionus), Cladocera (Moina, Daphnia, Diaphanosoma), Copepoda (Eurytemora, Tigriopus, Tisbe), dan Artemia (Mudjiman, 1989).

Cacing renik (Panagrellus redivivus) merupakan makanan yang sangat baik untuk larva ikan dan sangat mudah untuk dipelihara.Cacing renik berwarna putih dan tumbuh hingga berukuran $3 \mathrm{~mm}$. Beberapa peternak ikan menggunakan artemia sebagai makanan terbaik untuk larva ikan, namun penelitian telah menunjukkan bahwa larva ikan yang diberi cacing renik memiliki berat badan akhir rata-rata dan panjang total yang mirip pada ikan yang diberi pakan jenis lain.

Cacing renik memiliki keunggulan daripada Artemia. Mengkultur cacing renik tidak bergantung pada perubahan alam, mereka dapat tumbuh di dalam media kultur terus-menerus sepanjang tahun, dan pemeliharaan serta pemanenannya pun cukup mudah dan semua orang dapat melakukannya. Oleh karena itu, harga cacing renik sangat murah bila dibandingkan dengan artemia serta diameter cacing renik lebih kecil dari artemia yaitu $0,05 \mathrm{~mm}$ sedangkan diameter artemia $0,4 \mathrm{~mm}$ sehingga cacing renik sangat cocok bagi larva ikan. Oleh karena itu, pakan alami yang sesuai dengan bukaan mulut ikan pun harus diperhatikan.

Tujuan penelitian ini adalah untuk mengetahui pengaruh pemberian media berupa oatmeal, dedak padi, dan tepung tapioka terhadap pertambahan populasi cacing renik.

\section{MATERI DAN METODE}

Penelitianini dilakukan pada bulan Februari hingga April 2013 di Laboratorium Perikanan dan Laboratorium Biologi, Universitas Djuanda Bogor.

Bahan yang digunakan adalah inokulan cacing renik, bubur gandum, tepung tapioka, ragi instan, plastik mika, dan dedak halus. Peralatan yang digunakan adalah mikroskop, timbangan analitik, $\mathrm{pH}$ meter, dan wadah plastik berdimensi 7,5 $\mathrm{cm} \mathrm{x} \mathrm{7,5}$ $\mathrm{cm} \times 7,5 \mathrm{~cm}$.

Rancangan percobaan yang digunakan pada penelitian ini adalah Rancangan Acak Lengkap (RAL) dengan 3 perlakuan dan 3 ulangan serta menggunakan uji lanjut BNT (Beda Nyata Terkecil) bila hasil penelitian berbeda nyata. Perlakuan yang diberikan adalah jenis mediayang berbeda, yaitu bubur gandum/oatmeal (Perlakuan A), dedak padi (Perlakuan B), dan tepung tapioka (Perlakuan C).

Masing-masing bahan media yang akan digunakan terlebih dahulu ditimbang sebanyak 20 gram dan dimasukkan ke dalam wadah kultur. Setiap media diberi tambahan ragi sebanyak 0,15 gram, larutkan bahan-bahan tersebut menggunakan air hingga menjadi seperti bubur kemudian masukkan inokulan dengan biomassa 0,0098 g pada setiap wadah kultur setelah itu ditutup dengan rapat. Pada tutup masing-masing wadah diberi lubang kecil dengan ukuran yang sama.

Pelaksanaan sampling menggunakan Metode Kuadrat dengan cara mengambil sampel pada suatu luasan yang dapat berbentuk bujur sangkar, persegi enam, lingkaran, dan sebagainya. Sampling dilakukan setiap minggu, dari minggu ke-1 hingga minggu ke-8. Pengamatan dilakukan dengan cara meletakkan potongan plastik mika berukuran $0,5 \mathrm{~cm} \times 0,5 \mathrm{~cm}$ sebanyak 3 buah kemudian diletakkan pada bagian sisi 
dan tengah wadah. Populasinya diamati menggunakan mikroskop binokuler dengan perbesaran 40 kali.

Parameter yang diamati selama penelitian yaitu: dinamika populasi, laju pertumbuhan, rataan individu pada saat puncak populasi, lama pemeliharaan untuk mencapai puncak populasi, suhu, dan $\mathrm{pH}$ media.

\section{HASIL DAN PEMBAHASAN}

\section{Dinamika populasi}

Keadaan dinamika populasi cacing renik selama penelitian berbeda-beda pada setiap media.Pada media bubur gandum terjadi populasi tertinggi pada minggu ke-2.Pada media dedak terjadi populasi tertinggi pada minggu ke-3.Pada media tepung tapioka terjadi populasi tertinggi pada minggu ke5.Dinamika populasi cacing renik dapat dilihat pada Gambar 1.

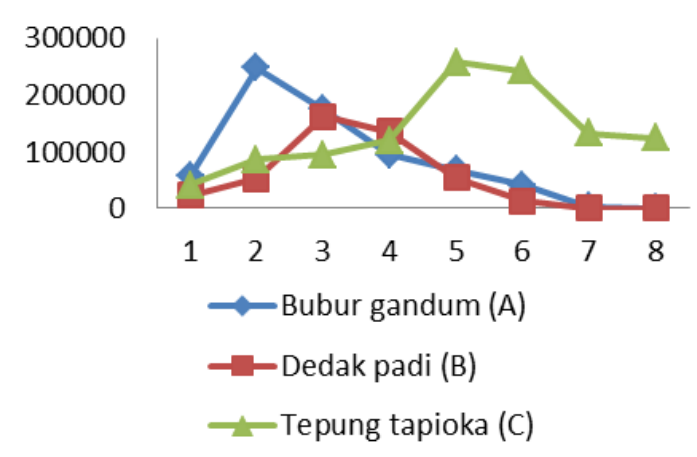

Gambar 1. Dinamika populasi rata-rata Cacing renik

\section{Laju Pertumbuhan Populasi}

Laju pertumbuhan populasi (\%) rata-rata cacing renik selama penelitian dapat dilihat pada Tabel 1.
Tabel 1. Laju Pertumbuhan populasi (\%) cacing renik selama penelitian

\begin{tabular}{cccc}
\hline \multirow{2}{*}{ Perlakuan } & \multicolumn{3}{c}{ Ulangan } \\
\cline { 2 - 4 } & A & B & C \\
\hline 1 & 46,3 & 27,4 & 17,9 \\
2 & 43,7 & 27,8 & 17,3 \\
3 & 45,1 & 28,1 & 18,1 \\
\hline Rata-rata & $45,0^{\mathrm{c}}$ & $27,8^{\mathrm{b}}$ & $17,8^{\mathrm{a}}$ \\
\hline
\end{tabular}

Keterangan: Superskrip huruf yang berbeda menunjukkan sangat berbeda nyata $(P<0,01) ; A=$ Bubur gandum, $\mathrm{B}=$ Dedak padi, $\mathrm{C}=$ Tepung tapioka.

Pertumbuhan populasi cacing renik terjadi pada minggu pertama sampai minggu ke-8 dengan peningkatan jumlah individu setiap perlakuan terlihat berbeda.Hal ini diduga karena media pengkulturan mengandung nutrient yang berbeda.Nutrient tersebut berupa kandungan karbohidrat, protein, dan lemak.

Karbohidrat pada media kultur akan digunakan oleh $S$. cerevisiae untuk berkembang biak dan kemudian akan menjadi makanan bagi cacing renik. Pada Gambar 1 terlihat bahwa setelah berada di puncak populasi, cacing renik mengalami pengurangan jumlah individu akibat adanya kematian.

Menurut Dasman (1964) dalam Irwan (1992), daya dukung lingkungan (carrying capacity) merupakan batas atas pertumbuhan suatu populasi.Apabila lebih dari batas atas maka pertambahan individu dalam populasi tidak dapat lagi didukung. Daya dukung media hidup cacing renik dipengaruhi oleh beberapa faktor, salah satunya ketersediaan nutrient dalam wadah kultur. Apabila dalam wadah kultur tidak ada penambahan nutrient maka akan terjadi persaingan dalam mengambil makanan. Hal tersebut dapat mengakibatkan sebagian cacing renik tidak memperoleh makanan dan bertahan hidup dengan nutrient yang tersisa. Kondisi ini menyebabkan kematian dan menurunnya jumlah populasi cacing renik pada wadah kultur.

Setelah diuji dengan tabel Sidik Ragam, diperoleh hasil bahwa perbedaan media 
kultur menyebabkan perbedaan yang nyata terhadap laju pertumbuhan pada taraf $1 \%$. Hasil uji BNT juga menyebutkan bahwa terdapat perbedaan yang nyata pada setiap perlakuan (A, B, dan C).

Pemberian media berbeda pada setiap perlakuan menunjukkan pengaruh yang nyata terhadap laju pertumbuhan serta jumlah individu saat mencapai puncak populasi setelah diuji statistik $(\mathrm{P}<0,01)$.

Laju pertumbuhan populasi tertinggi pada media bubur gandum (A) yaitu $45,0 \%$, media dedak padi (B) yaitu $27,8 \%$, dan terendah pada media tepung tapioka (C) yaitu $17,8 \%$. Hal ini dikarenakan media bubur gandum dan dedak padi mengalami proses fermentasi lebih cepat dibandingkan dengan tepung tapioka, sehingga mengindikasikan bahwa media kultur sudah banyak mengandung $S$. cerevisiae.

Cacing renik dapat tumbuh dan berkembang dengan baik karena tersedia makanan yang cukup berupa $S$. cerevisiae, karena cacing renik termasuk nematoda pemakan mikroorganisme.Tepung tapioka mengalami proses fermentasi yang lambat karena adanya kandungan amilopektin, sehingga menyebabkan tepung tapioka tidak larut dalam air dan $S$. cerevisiae tidak dapat melakukan proses fermentasi secara cepat. Amilopektin merupakan komponen pati yang mempunyai rantai cabang, terdiri dari satuan glukosa yang bergabung melalui ikatan $\alpha-(1,4)$ D-glukosa dan $\alpha-(1,6)$ Dglukosa (Schwartd dan Zelinskie, 1978). Tepung tapioka memiliki kandungan amilopektin 83\% dan 17\% kadar amilosa (Sayangbati, 2013).

Rataan jumlah cacing renik dan hari puncak populasi disetiap perlakuan dapat dilihat pada Tabel 2 .
Tabel 2. Rata-rata individu saat puncak populasi (ekor) dan hari puncak populasi

\begin{tabular}{ccc}
\hline Perlakuan & $\begin{array}{c}\text { Rata-rata } \\
\text { individu } \\
\text { (ekor) }\end{array}$ & $\begin{array}{c}\text { Hari } \\
\text { puncak } \\
\text { populasi }\end{array}$ \\
\hline A & $249.338^{\mathrm{a}}$ & 14 \\
B & $162.563^{\mathrm{b}}$ & 21 \\
C & $259.088^{\mathrm{a}}$ & 35 \\
\hline
\end{tabular}

Keterangan:Superskrip huruf yang berbeda menunjukkan sangat berbeda nyata $(\mathrm{P}<0,01)$; $\mathrm{A}=$ Bubur gandum, $\mathrm{B}=$ Dedak padi, $\mathrm{C}=$ Tepung tapioka.

Setelah diuji dengan tabel Sidik Ragam, diperoleh hasil bahwa perbedaan media kultur menyebabkan perbedaan yang nyata terhadap jumlah cacing renik saat puncak populasi $(\mathrm{P}<0,01)$. Hasil uji BNT juga menyebutkan bahwa perlakuan $B$ terdapat perbedaan yang nyata dengan perlakuan $\mathrm{A}$ dan C.

\section{Parameter Media dan Lingkungan}

Parameter media dan lingkungan yang meliputi $\mathrm{pH}$ mediasangat mempengaruhi perkembangan populasi cacing renik.Perbedaan $\mathrm{pH}$ setiap media dan data suhu lingkungan dapat dilihat pada Tabel 3.

Tabel3. Kisaran hasil pengukuran keasaman dan suhu selama pengkulturan

\begin{tabular}{|c|c|c|c|}
\hline \multirow{2}{*}{ Parameter } & \multicolumn{3}{|c|}{ Perlakuan Media } \\
\hline & $\mathrm{A}$ & B & $\bar{C}$ \\
\hline Suhu ( $\left.{ }^{\circ} \mathrm{C}\right)$ & $25-30$ & $25-30$ & $25-30$ \\
\hline pH & $4,0-6,7$ & $4,0-6,0$ & $5,4-7,3$ \\
\hline
\end{tabular}

Tabel 3 menunjukkan puncak populasi yang diperoleh selama penelitian.Terlihat bahwa setiap media mempunyai jumlah populasi yang berbeda dengan waktu pencapaian yang berbeda pula. Hal ini menunjukkan bahwa, jenis media berpengaruh sangat nyata terhadap jumlah individu $(\mathrm{P}<0,01)$ dan waktu puncak 
populasi. Perlakuan pada media bubur gandum dan tepung tapioka menghasilkan jumlah individu terbanyak, masing-masing jumlahnya adalah 249.338 ekor dan 259.088 ekor.Pada media dedak padi menghasilkan jumlah cacing renik paling sedikit yaitu 162.563 ekor.Hal ini terjadi karena kualitas nutrisi dedak padi yang rendah, sehingga berpengaruh kepada jumlah populasi cacing renik. Secara organoleptik, kualitas dedak padi bermutu rendah dapat diketahui jika digenggam tidak akan menggumpal karena banyak campuran sekam (Kushartono, 2000).

Nutrisi menghasilkan energi yang kemudian digunakan oleh cacing renik untuk pertumbuhan dan melakukan aktifitas biologis lainnya.Sumber energi berupa karbohidrat, lemak, dan protein merupakan hal yang sangat diperlukan oleh makhluk hidup untuk pertumbuhan dan juga untuk beraktivitas (Sediaoetama, 2000).

Kisaran suhu lingkungan dan nilai $\mathrm{pH}$ pada setiap perlakuan selama penelitian berada dalam kisaran yang mendukung kehidupan cacing renik.Cacing renik dapat tumbuh pada kisaran suhu 20-25 C (Figueroa, 2009). Menurut Ricci (2003) ketika suhu mulai meningkat atau menurun di bawah kisaran 20-28 ${ }^{\circ} \mathrm{C}$, akan mempengaruhi produksi cacing renik. Pada saat penelitian terlihat bahwa cacing renik tumbuh optimal pada kisaran $\mathrm{pH}$ 5,0-6,2 dan mengalami kematian saat mencapai $\mathrm{pH}$ 4,0 .

\section{KESIMPULAN}

Perbedaan media kultur berupa bubur gandum, dedak padi, dan tepung tapioka menyebabkan perbedaan yang nyata terhadap laju pertumbuhan cacing renik dan rataan jumlah individu pada puncak populasi. Laju pertumbuhan tertinggi dihasilkan oleh perlakuan A (bubur gandum) yaitu 45,0 \% dan terendah dihasilkan oleh perlakuan $\mathrm{C}$ yaitu $17,8 \%$.

Puncak populasi tertinggi dicapai pada saat rata-rata jumlah maksimum individu tertinggi dihasilkan oleh perlakuan $\mathrm{C}$ (tepung tapioka) sebanyak 259.088 ekor, sedangkan rata-rata jumlah maksimum individu cacing renik terendah terjadi pada perlakuan B (dedak padi) sebanyak 162.563 ekor. Lama pemeliharaan yang menghasilkan puncak populasi tercepat adalah perlakuan A yaitu 14 hari.

\section{DAFTAR PUSTAKA}

Figueroa LJ. 2009. Nematodo de vida libre Panagrellus redivivus (Goodey, 1945):Una alternativa para la alimentación inicial de larvas de peces y crustáceos. De La Universad Autonoma De Aguascalienes. Numero 45, (4-11). Septiembre-Diciembre.

Grace MR. 1977. Cassava Processing.Food and Agriculture Organization of United Nations, Roma.

Irwan ZD. 1992. Prinsip-prinsip Ekologi dan Organisasi: Ekosistem Komunitas dan Lingkungan. Bumi Aksara. Jakarta.

Kushartono B. 2000 .Penentuan Kualitas Bahan Baku Pakan Dengan Cara Organoleptik. Prosiding Lokakarya Fungsional Non Peneliti.Pusat Penelitian dan Pengembangan Peternakan.Badan Penelitian dan Pengembangan Pertanian. Departemen Pertanian. Hal 217-223 .

Mudjiman A. 1989. Udang Renik Air Asin (Artemia salina). Jakarta: Bhratara Niaga Media.

Ricci M. 2003. Development of a low-cost technology for mass production of the free-living nematode Panagrellus redivivus as an alternative live food for first feeding fish larvae. Appl. Microbiol. Biotechnol., 60: 556- 559.

Sayangbati F. 2013. Karakteristik Fisikokimia Biskuit Berbahan Baku Tepung Pisang Goroho (Musa Acuminate,Sp). Skripsi Fakultas Pertanian Universitas Sam Ratulangi, Manado.

Sediaoetama AD. 2000. Ilmu Gizi Untuk Mahasiswa dan Profesi.Jilid 1. Cet.4. Jakarta : Dian Rakyat.

Schwartd BJ, Zelinskie AJ. 1978. The Binding and Disintegrant Properties of the Corn Starch Fracions Amylose and 
Amylopectin. Pharmaceutical Research

Laboratories West Point. Pensylvania.

463-483. 